Discourse and Communication for Sustainable Education, vol. 12, no. 1, pp. 22-41, 2021

\title{
Self-Efficacy of Physical and Health Education Student Teachers in the Quebec Context
}

\author{
Salem Amamou \\ University of Quebec in Abitibi-Temiscamingue, Quebec, Canada \\ CRIFPE-Sherbrooke \\ François Vandercleyen and Jean-François Desbiens \\ University of Sherbrooke, Quebec, Canada \\ CRIFPE-Sherbrooke
}

\begin{abstract}
Pre-service training is a critical period for establishing the beliefs of future teachers in their ability to successfully assume their responsibilities as teachers. One of the goals of teacher education programs would therefore be to cultivate a high sense of competence among students.

For this purpose, a scale to measure the perception of self-efficacy (PSE) among Quebec physical and health education trainees during teaching has been developed and empirically validated. Teacher trainees $(\mathrm{n}=232)$ enrolled in $3^{\text {rd }}$ and $4^{\text {th }}$ year in the Bachelor of Education in Physical and Health Education (PHE) in four different university programs in Quebec participated in the study.

Subsequent exploratory and quasi-confirmatory factor analyses led to the development of an instrument with 19 items divided into three factors, explaining $66.10 \%$ of the total variance. The convergent and divergent measures of validity are satisfactory, as are those of the reliability of the three scales (upper lower limit: .78 to .93). Finally, the RMSR, CFI, RMSEA and NNFI indices show an excellent goodness of fit of the model obtained.
\end{abstract}

Key words: self-efficacy, validation, measurement scale, pre-service teacher, health education

\section{Introduction}

The practicum has for many years been considered a pivotal period in the education of future teachers (Dassa \& Nichols, 2019; Desbiens, Correa-Molina, \& Habak, 2019; Desbiens, Habak, \& Martineau, 2019; Koskela \& Ganser, 1998). It is a challenging undertaking for them (Gurl, 2019). This period more or less intensive and prolonged can be stressful, anxiety-provoking, and can even become a real test of endurance (Kosnik, 2009; Ma \& Cavanagh, 2018). During this period, the trainee wants to experience 
success and is driven by the desire to perform and obtain recognition from his or her mentors in this crucial experience (Flynn \& Chow, 2018). In addition, the student teacher is often required to reframe idealistic visions of himself or herself and of the teaching profession. Indeed, during his/her practicum experience, she/he is confronted with identity issues that often go beyond self, questioning individual personality, values, conceptions and professional aspirations (Desbiens, Borges, \& Spallanzani, 2012). The student teacher may therefore be preoccupied and experience adjustment difficulties (Desbiens et al., 2019a), some of which are expressed in episodes of depression or intense anxiety (Desbiens et al., 2018).

In this context, trainees come to doubt their ability to carry out their responsibilities successfully as teachers. As such, the practicum experience influences the student's sense of self-efficacy in terms of his or her ability to teach (Mukamurera \& Gingras, 2005), that is, the development of a more or less strong belief in personal ability to organize his or her action and to take the necessary actions to achieve the desired results. Hoy and Spero (2005) point out that a teacher's perception of personal effectiveness in performing a specific task is a future-oriented judgment that relates to the teacher's perceptions of competence to perform that task rather than to the actual level of competence. It refers to a teacher's "belief in his or her own" ability to perform a specific task (Yilmaz, 2011). This is an important distinction because people regularly over- or under-estimate their actual abilities (Dassa \& Nichols, 2019). This is particularly true when asking preservice teacher education students to report their perceptions of their self-efficacy (PSE) in relation to a specific task (e.g., classroom management) at different points in their path (Amamou, Desbiens, Spallanzani, \& Vandercleyen, 2017). As they progress from being a trainee to being a teacher, and based on past intervention experiences, their perceptions of their level of teaching competencies often change, sometimes positively, sometimes negatively (Dassa \& Nichols, 2019). Trainees thus come to be concerned about the gap between their perception of self-efficacy in relation to teaching practices and their actual performance. An implicit goal of teacher education programs would therefore be to provide trainees with a variety of experiences that lead them to develop self-efficacy in relation to different professional competencies. In Quebec, pre-service teachers must develop 12 professional competencies to a degree deemed sufficient (Government of Quebec, 2001) in order to obtain their teaching certificate. Even if, at the end of their pre-service training, trainees demonstrate such a degree of mastery, do they still feel effective in implementing them in the context of health and physical education teaching?

\section{Theoretical Framework}

In this part, the PSE will first be defined. The transposition of the concept of PSE to the context of teaching and the four sources are presented. Next, we examine, in the Quebec context, the training approach based on the development of professional skills. More specifically, competencies related to the act of teaching will be discussed. Finally, we explore the place of the PSE in teaching in the development of the professional competencies of student teachers. 


\section{Self-Efficacy Defined}

Self-efficacy refers to “a person's judgment of his or her ability to organize and use the various means at his or her disposal to successfully complete a given task" (Bandura, 1986, p. 391). When applied to the context of teaching, PSE represents a teacher's belief in his or her ability to organize and use a variety of resources necessary for successful teaching in order to get the desired results and influence student behaviour and learning (Bandura, 1977; Klassen, Tze, Betts, \& Gordon, 2011). It is a construct based on two aspects: effectiveness expectations and outcome expectations (Bandura, 1977). According to Gibson and Dembo (1984), the first refers to the teacher's confidence in having students achieve learning, while the second refers to the teacher's confidence in professional ability to have a positive impact on student learning.

PSE plays a major role in almost all human actions (Bandura, 1997; Gardner \& Pierce, 1998). Many studies have shown that PSE is known to play a key role in the motivational dynamics among teachers. In fact, the greater the PSE, the higher the goals and commitment tend to be. Teachers with a strong PSE are known to be more open to experiment, more willing to engage with students and more eager to improve (Hoy \& Spero, 2005; OECD, 2014; Salite, 2016).

According to Bandura's (2003) model, there are four sources through which PSE develops: 1) enactive mastery, 2) vicarious (or modeling) experiences, 3 ) verbal persuasion, and 4) emotional state. The first source is based on personal mastery of to-do tasks. The more successful a trainee's teaching experience is, the more likely the candidate is to believe in his/ her teaching abilities. The second source is based on social comparison: the fact that a trainee observes a peer succeed, despite a situation that is considered critical at first sight, can influence or even reinforce personal belief in his/ her own ability to succeed in the task being observed. The third source means that through questioning, advice, encouragement and reinforcement, trainees may gradually feel that they have the ability to successfully complete a task that they previously thought was difficult to achieve. Finally, the fourth source appears when the trainee associates an emotional state (e.g., anxiety) and bodily feelings (e.g., stomach aches, headaches, palpitations) with the completion of a given task or category of tasks, which may lead to success or failure.

\section{The Act of Teaching at the Heart of a Training Approach Based on the Development of Professional Competencies}

In Quebec, in order to harmonize the transformations initiated in the school system and to create a training program based on increased professionalization, the Ministère de l'Éducation, du Loisir et du Sport (MELS) published "Les orientations de la formation à l'enseignement, les compétences professionnelles” in 2001 (Teacher Training - Orientations - Professional Competencies), a document framed by two general orientations: providing professional training to teacher candidates and training cultivated teachers (Government of Quebec, 2001). This document identifies and defines twelve professional competencies to be developed in future teachers and presents benchmarks for applying these recommendations (Jobin \& Gauthier, 2009). It is expected that, at the end of their initial training, all candidates, regardless of the subject taught, will master these professional competencies. 
The term "professional competency" is defined as: "a know-how to act that is based on the mobilization of resources and that is exercised in a professional situation" (Government of Quebec, 2008, p. 4). Each of the statements expressing professional competency is specified by a general description of the meaning of the competency and a number of components. These components therefore constitute guidelines to aid universities in the specific choices they must make with regard to each of the professional objects of knowledge when developing their teacher education programs. A level of mastery specific to each of the professional competencies, regardless of clienteles, teaching orders and disciplines is also outlined in order to determine what can reasonably be expected of a person entering the teaching profession (Government of Quebec, 2001).

The twelve professional competencies expected of teachers in Quebec have been grouped into four dimensions: the foundations of the profession, the act of teaching, the social and academic context, and professional identity (Government of Quebec, 2001). Within the framework of our research, we are particularly interested in the act of teaching, which includes the following competencies: Competency 3 (C3) "Design teaching-learning situations for the content to be taught, based on the students concerned and the development of the competencies targeted in the training program" (p. 75); Competency 4 (C4): "Pilot teaching-learning situations for the content to be taught, according to the students concerned and the development of the competencies targeted in the training program" (p. 75); Competency 5 (C5), "Evaluate the progress of learning and the degree to which students acquire competencies in the content to be taught" (p. 91) and Competency 6 (C6), "Plan, organize, and supervise the operating mode of the classroom group in order to promote student learning and socialization” (p. 97).

\section{The Place of Self-Efficacy in Teaching in the Development of Professional Competencies}

As explained earlier, beliefs about self-efficacy play a central role in virtually all human actions (Bandura, 1977; Gardner \& Pierce, 1998). The PSE therefore influences teachers in their choices, decisions and actions (Gaudreau, 2011). Research shows that a strong PSE enables teachers to engage with confidence in solving work-related problems (Bandura, 2003; Gibson \& Dembo, 1984). Klassen and Chiu (2010) report that teachers who report higher self-efficacy also report higher job satisfaction and less stress, which, in return, may also influence motivation and academic achievement of their students (Gaudreau Royer, Beaumont, \& Frenette, 2012; Skaalvik \& Skaalvik, 2007). Several studies have demonstrated positive relationships between PSE and high levels of achievement, motivation, enthusiasm, and commitment among both teachers and students (Caprara, Barbaranelli, Steca, \& Malone, 2006; OECD, 2014).

In the context of initial training, many teacher candidates enter the practicum with a representation of themselves as teachers that is constructed primarily from their previous intervention experiences (Behets \& Vergauwen, 2006; Capel \& Breckon, 2014). Other teacher candidates who have limited prior intervention experience rely primarily on their own beliefs about effectiveness in relation to their ability to teach (Nichols, 2011), largely built from their experience as students (Garrahy, Cothran, \& Kulinna, 2002; Matanin \& Collier, 2003). In both situations, these trainees may come to over- or under-estimate their PSE in teaching, which may impact on their professional development. While a larger PSE may be helpful, could an oversized PSE have disadvantages? 
While several studies indicate that the majority of young teacher candidates feel ineffective to carry out their teaching duties (Beckers, 2007; Beckers, Andrianne, Bourguignon, Jardon, Jaspar, \& Mathieu, 2002; Dejean, 2010; Veenman, 1984), other researchers are surprised to find high scores on the self-confidence of trainee teachers (Amamou, Desbiens, Spallanzani, \& Vandercleyen, 2017; Dassa \& Nichols, 2019). At different points in their initial formation, rather than experiencing insecurity or low PSE, trainees appear to have a high or even very high PSE about their teaching practices. Although this may be related to the first source of PSE, enactive experiences (Bandura, 2003 ) - in other words, trainees' experiences are so positive that they perceive their ability to carry out teaching practices to be high (Clark, Byrnes, \& Sudweeks, 2015; Flores, 2015) - yet research findings by Dassa and Nichols (2019) show that trainees' perceptions of self-efficacy are significantly higher than their actual competencies. This phenomenon, described as "unrealistic optimism" (Weinstein, 1989), appears to be detrimental to the professional development of young teachers (Ingersol, Merrill, \& Stuckey, 2014) and may partly explain why as many as $50 \%$ of new teachers drop out of the profession during the first five years of their careers (Ingersoll, 2001).

According to Dassa and Nichols (2019), if a teacher candidate feels that his/ her PSE for a specific teaching task is higher than it actually is, she/he may become confused when that task becomes more challenging. In addition, this overestimation can prevent trainee teachers from reflecting on their practices and therefore doubting their abilities. Although doubt has often been associated with experiences of failure, lack of confidence, stress, and other similar factors, it can be considered 'healthy' (Weinstein, 1989; cited in Dassa \& Nichols, 2019). Doubt allows the emergence of a form of questioning related to the effectiveness of certain teaching practices, which is necessary to improvement (Flynn \& Chow, 2018; Jones \& Nimmo, 1999; Wheatley, 2002; Heasly et al., 2020). Other potential benefits may arise from a sense of doubt about self-efficacy by helping to create an imbalance or a reframing of idealistic visions (Flynn \& Chow, 2018). Thus, it seems important that institutions, through their teacher education programs and practicum schemes, expose student teachers to "healthy" doubts about their effectiveness in order to move them out of their comfort zone and provoke learning. In this regard, Desbiens et al. (2019a) argue that the situations that are most conducive to learning are those that lead trainees to confront new problems and/or challenges that require "a certain amount of risk taking, initiative, creativity, self-control, method, and reflective ability" (Lévy-Leboyer, 2009, p. 7). Although these situations make the trainees have "healthy" doubts about their ability to succeed, they also make them aware that knowledge and competencies are subject to adjustment and that they are in continuous development (Dassa \& Nichols, 2019).

Consequently, the period of pre-service teacher education is critical in establishing the beliefs of future teachers. One of the goals of teacher education programs would be to cultivate a high sense of competency in teacher candidates. The PSE is therefore a prime target for intervention and a powerful lever to help trainees become fully engaged in their teacher education process and to develop professionally in teaching. Indeed, trainees with a high level of PSE are motivated by a state of mind that makes them more willing to learn the profession. But how do Quebec PHE teacher trainees perceive their level of PSE in relation to the professional competencies related to the act of teaching?

The measuring instruments currently available do not or only partially answer this question. Although several scales measuring PSE in education have been developed over 
the last 30 years, the criticism often levelled against the five most commonly used scales (Bandura, 1997; Gibson \& Dembo, 1984; Schwarzer, Schmitz, \& Daytner, 1999; Sharma, Loreman, \& Forlin, 2012; Tschannen-Moran \& Woolfolk Hoy, 2001), or other measurement scales, concern the lack of rigour in the steps that have been taken to verify their psychometric qualities. One of the recurring limitations is that the fidelity and validity indices reported are not all satisfactory (Amamou, Ben Alaya, Desbiens, \& Vandercleyen, 2018) or even statistically valid (Bourque, Doucet, LeBlanc, Dupuis, \& Nadeau, 2019). Another frequent limitation is the lack of contextualization of the scales used, which prevents the establishment of any form of scientific validity.

\section{The Objectives of the Study}

There is currently no empirically validated measurement scale in the Quebec context that can measure the perceptions of student teachers regarding their SE when they teach and, more specifically, the attainment of professional competencies related to the act of teaching, as set out in the Quebec referential of professional competencies (Government of Quebec, 2001). To meet this need, the purpose of this article is to present the elaboration, empirical validation, and exploratory and quasi-confirmatory verification of the psychometric qualities of a questionnaire on the perceptions of Quebec PHE trainee teachers regarding their PSE in relation to the actions associated with the four professional competencies related to the act of teaching.

\section{Research Methodology}

\section{Questionnaire Development/Elaboration Phase}

The development of the questionnaire was based on the recommendations made by Bandura $(2012 ; 2006)$ in his guide to constructing a measurement scale for PSE. It was also based on the part of the Quebec referential of professional competencies (Government of Quebec, 2001) devoted to the four competencies (C3, C4, C5 and C6) related to the act of teaching.

First, the review of the four competencies related to the act of teaching, their components and their respective levels of mastery was conducted in collaboration with three experts in the field of physical activity intervention. It led to the formulation of 36 statements $(\mathrm{C} 3=6 ; \mathrm{C} 4=17 ; \mathrm{C} 5=7 ; \mathrm{C} 6=6)$. Adjustments in wording, content and organization were made by the research team and the three experts in order to adapt the statements to the context of physical and health education teaching. Following the recommendations of Bandura $(2012 ; 2006)$, the statements were formulated in the present tense using the verb pouvoir conjugated in the first person singular ("I can") (Bandura, 2012). Next, the format used for the response choices is that of a ten-level ordinal scale, ranging from 0 ("I cannot perform this competency at all") to 10 ("I can perform this competency completely"), going through an intermediate level of confidence at 5 ("I can perform this competency moderately") (Bandura, 2006).

Secondly, to test the questionnaire, a qualitative pilot study was conducted with a sample comparable to our population. Five fourth-year trainees enrolled in the Bachelor of Education in Physical and Health Education at the Université de Sherbrooke (Quebec, Canada) completed the questionnaire and commented on the readability, clarity and 
comprehensibility of the statements. The version of the instrument that was tested therefore consisted of a total of 36 statements. First, the trainees identified two disciplines that they would teach or had actually taught during their practicum. For each, they then specified their perceived level of expertise. Next, they were asked to provide their perceptions of their level of confidence in achieving each of the stated competencies for each of the identified disciplines. Minor adjustments to the terminology used or the wording of some questions were made in response to the suggestions of these respondents.

\section{Exploratory and Quasi-Confirmatory Validation Phases of the Instrument}

\section{Data Collection - Completion of the Questionnaire}

Data collection was carried out with a non-probability clustered sample (Fortin \& Gagnon, 2016) of 232 trainee teachers (men: $58.30 \%$; women: $41.70 \%$; average age: $24.49 \pm 3.43$ years old $)$ of internships III ( $3^{\text {rd }}$ year; $\left.55.20 \%\right)$ and IV $\left(4^{\text {th }}\right.$ year; $44.80 \%$ ) enrolled in a Bachelor of Education in Physical and Health Education program in four different Quebec universities (Université du Québec à Montréal (UQAM) (48.70 \%), Université du Québec à Trois-Rivières (UQTR) (13.80\%), Université de Montréal (U de M) $(8.20 \%$ ) and Université de Sherbrooke (U de S) $(29.30 \%)$. A paper questionnaire was submitted to the students to ensure a high rate of valid and usable responses. Data collection was carried out in the winter and fall 2018 sessions, at the end of practicum preparation and assessment meetings, just before $(n=73 ; 31.50 \%)$ and after $(n=159$; $68.50 \%$ ) practicum. It was not possible to systematize the matching of data collected during the pre-training and post-training periods.

All respondents were informed that participation in this project was voluntary and that the information collected from the questionnaire would remain strictly confidential and would be treated in a manner that would preserve their anonymity.

A mixed strategy was adopted to determine the sample size. This was based on the guidelines provided by Beavers, Lounsbury, Richards, Huck, Skolits and Esquivel (2013). A sufficiently large sample size $(\mathrm{n}=232>150)$ was selected and then the ratio of participants per variable was determined to be greater than $5(6.44>5)$. Afterwards, we found that 14 of the 17 statements $(82.35 \%)$ had a loading greater than .70 , suggesting that the model shows some stability. The sample drawn therefore meets sufficient requirements to conduct the proposed analyses.

\section{Data Analysis}

First, for each of the statements or items and using SPSS (Version 24) and Factor 10.5 software, we conducted an in-depth analysis of the univariate (Razali \& Wah, 2011) and multivariate (Mardia, 1970) distributions of the data. These analyses show that none of the variables under study follow a normal distribution. The examination of the distributions was followed by a verification of the conditions and basic premises of the factor analysis. Specifically, this verification concerned the Bartlett's test (Stafford \& Bodson, 2006), the value of the determinant (Field, 2013) and the Kaiser-Meyer-Olkin index (KMO) (Bourque, Poulin, \& Cleaver, 2006). As shown in Table 1, the values obtained confirmed that the premises of the factor analysis were met and that it was possible to proceed further. 
A series of exploratory factor analyses were conducted using the minimum rank factor analysis (MRFA) estimation method (Baglin, 2014) and a satisfactory factor solution was identified. This was then subjected to a series of quasi-confirmatory factor analyses using the robust unweighted least squares (RULS) estimation method (Baglin, 2014). Given the irregularity of the data distribution, exploratory and quasi-confirmatory factor analyses were performed using polychoric correlations. Baglin (2014) and Flora and Curran (2004) recommend their use when the univariate distributions of ordinal variables are skewed and when the data correspond to scores obtained using ordinal scales.

Horn's extraction method (O'Connor, 2000) was used to determine the number of factors to be extracted. For the selected factors, the promin-type oblique rotation was chosen. This method was chosen because, quite often in the social sciences and humanities, behaviours and perceptions do not always fall clearly into disjunct units (Costello \& Osborne, 2005) and it was anticipated that the latent constructs that would emerge from this analysis would not be independent of each other.

To establish the internal consistency of the identified factors, the omega, greater lower bound (GLB) and Cronbach's alpha estimators for ordinal scale were calculated using SPSS. We referred to the recommendations of Bourque et al. (2019), which suggest the use of omega in the case where the number of statements making up a given scale is low and the use of the greater lower bound (GLB) in other scenarios. Cronbach's alpha (for ordinal scale) is presented here, despite the fact that it is the subject of many criticisms, because it is widely used in educational science research (Bourque et al., 2019).

\section{Research Findings}

In this section, we present the results of the exploratory and quasi-confirmatory factor analyses. We also present the structure of the measurement scale resulting from these validation approaches, as well as its psychometric qualities.

\section{Results of the Exploratory Factor Analysis}

Following six waves of exploratory analyses, 17 statements were removed for any of the following reasons: 1 . multiple loadings $\geq .32$ with discrepancies between factors $\leq .20 ; 2$. factor loadings $\leq .40 ; 3$. community values too low $(<.40)$. We have therefore gradually gone from 36 to 19 statements. The other parameters measured (Table 2) indicate that the correlations between the model variables are significantly different from 0 (Bartlett's test: X2 $=4814.5, \mathrm{ddl}=171, \mathrm{p}=.00001$ ) and are unlikely to cause a collinearity problem (determinant: .00001). The KMO index is very satisfactory at .93 (Stafford \& Bodson, 2006). 


\section{Table 1}

Summary of the Results of the Exploratory Factor Analysis

\begin{tabular}{|c|c|c|c|}
\hline \multirow{2}{*}{ Parameters considered } & \multicolumn{3}{|c|}{ Results } \\
\hline & Obtained & & Reference values \\
\hline Determinant & .00001 & $=$ & .00001 (Field, 2013) \\
\hline KMO index & .93 & $>$ & .60 (Bourque et al., 2006) \\
\hline \multicolumn{4}{|l|}{ Internal consistency } \\
\hline Factor $1(\mathrm{n}=8)$ & $\begin{array}{c}\text { Omega }=.93 \\
\text { GLB }=.94 \\
\alpha_{\text {Cronbach }} \text { ordinal }=.93 \\
\text { Omega }=.82\end{array}$ & $>$ & .80 (Bourque et al., 2019) \\
\hline Factor $2(\mathrm{n}=6)$ & $\begin{array}{c}\text { GLB }=.82 \\
\alpha_{\text {Cronbach }} \text { ordinal }=.81\end{array}$ & $>$ & .80 (Bourque et al., 2019) \\
\hline Factor $3(\mathrm{n}=6)$ & $\begin{array}{c}\text { Omega }=.76 \\
\text { GLB }=.78 \\
\alpha_{\text {Cronbach }} \text { ordinal }=.74\end{array}$ & $<$ & .80 (Bourque et al., 2019) \\
\hline Bartlett's test & \multicolumn{3}{|c|}{$4814.5, \mathrm{dl}=171, \mathrm{p}=.00001$} \\
\hline Parallel axis 3 factor-analysis & \multicolumn{3}{|c|}{3 factors (Horn, 1965) } \\
\hline Number of statements withdrawn & \multicolumn{3}{|c|}{$17 / 36$ (47.22 \%) } \\
\hline
\end{tabular}

According to the exploratory analysis, three factors emerge. They explain a total variance of $66.10 \%$. As shown in Table 2, factor 1 is composed of six statements. Loadings range from .64 to .80. This one has a relative inertia of $49.30 \%$. It is the product of merging competencies 3 (Planning) and 4 (Piloting) for actions that lead to "designing and piloting teaching-learning situations for the content to be taught, according to the students concerned and the development of the competencies targeted in the training program". For its part, factor 2 is composed of seven statements. The loadings vary between .66 and .89. It groups together the components related to Competency 5, "Evaluate the learning progression and the degree of acquisition of competencies for the content to be taught", and explains $9.91 \%$ of the variance. Finally, factor 3 is composed of six statements. Loadings vary between .70 and .87 . This third factor is made up of components associated with Competency 6, "Plan, organize, and supervise the operating mode of the classroom group in order to promote student learning and socialization." It has a relative inertia of $6.89 \%$. All statements have a community above the recommended .40 threshold (Baglin, 2014). As shown in Table 2, three internal consistency estimators, omega, greatest lower bound (GLB), and Cronbach's ordinal alpha (i Cronbach ordinal) were used. The values obtained for these three estimators are above the .80 threshold proposed by Bourque et al. (2019) for the first two factors, but they range from .74 to .78 for factor 3 , which is lower than the .80 threshold but higher than the .70 threshold commonly used in the scientific literature (Hair et al., 2006; Peterson, 1994). 


\section{Table 2}

Loading Statements by Factor and Quality of Representation in Exploratory Factor Analysis

\begin{tabular}{|c|c|c|c|}
\hline & Statements retained & Loadings & Communities \\
\hline \multirow[t]{6}{*}{$\begin{array}{c}\text { Factor } \\
1\end{array}$} & $\begin{array}{l}\text { E.5 Anticipate obstacles and difficulties that students may } \\
\text { encounter in a teaching-learning situation. }\end{array}$ & .72 & .51 \\
\hline & $\begin{array}{l}\text { E. } 6 \text { Provide learning situations that allow for the integration } \\
\text { of the competencies covered by the training program. }\end{array}$ & .64 & .51 \\
\hline & $\begin{array}{l}\text { E. } 7 \text { Create conditions for students to engage in teaching- } \\
\text { learning situations taking into account their characteristics. }\end{array}$ & .80 & .57 \\
\hline & $\begin{array}{l}\text { E. } 8 \text { Guide students through appropriate interventions in the } \\
\text { completion of learning tasks. }\end{array}$ & .69 & .59 \\
\hline & $\begin{array}{l}\text { E.13 Clearly present the activity (instructions, rules, criteria, } \\
\text { et al.). }\end{array}$ & .74 & .58 \\
\hline & E.14 Use adequate demonstration. & .77 & .53 \\
\hline \multirow[t]{7}{*}{$\begin{array}{c}\text { Factor } \\
2\end{array}$} & $\begin{array}{l}\text { E.24 Gather information to identify students' strengths and } \\
\text { challenges. }\end{array}$ & .66 & .61 \\
\hline & $\begin{array}{l}\text { E. } 25 \text { Adapt my interventions according to the information } \\
\text { collected beforehand in order to promote learning progression. }\end{array}$ & .70 & .95 \\
\hline & $\begin{array}{l}\text { E.26 Establish a balance sheet of the students' achievements } \\
\text { in order to assess their degree of acquisition of competencies. }\end{array}$ & .76 & .64 \\
\hline & E.27 Building tools to assess competency acquisition. & .70 & .59 \\
\hline & $\begin{array}{l}\text { E. } 28 \text { Communicate clearly and explicitly to students their } \\
\text { results from the evaluation process. }\end{array}$ & .85 & .66 \\
\hline & $\begin{array}{l}\text { E. } 29 \text { Communicate to the various stakeholders (colleagues, } \\
\text { parents.) the students' results from the evaluation process. }\end{array}$ & .89 & .64 \\
\hline & $\begin{array}{l}\text { E. } 30 \text { Collaborate with the school team in determining the } \\
\text { desired pace and stages of the pupils' learning progression. }\end{array}$ & .69 & .64 \\
\hline \multirow[t]{6}{*}{$\begin{array}{l}\text { Factor } \\
3\end{array}$} & $\begin{array}{l}\text { E.31 Establish rules and routines for effective classroom } \\
\text { activities. }\end{array}$ & .68 & .76 \\
\hline & $\begin{array}{l}\text { E.32 Communicate my expectations about appropriate } \\
\text { behaviour to students. }\end{array}$ & .73 & .66 \\
\hline & $\begin{array}{l}\text { E. } 33 \text { Involve students in establishing the rules of the class- } \\
\text { room. }\end{array}$ & .76 & .50 \\
\hline & $\begin{array}{l}\text { E. } 34 \text { Adopt strategies to prevent the occurrence of disruptive } \\
\text { behaviour. }\end{array}$ & .87 & .69 \\
\hline & E.35 Intervene efficiently when disruptive behaviour occurs. & .79 & .58 \\
\hline & E.36 Maintain a climate conducive to learning. & .78 & .64 \\
\hline
\end{tabular}

\section{Results of the Quasi-Confirmatory Factor Analysis}

A wave of quasi-confirmatory factor analyses using the robust unweighted least squares (RULS) estimation method was carried out to verify the adequacy of the resulting model. The results (Table 3) obtained in this quasi-confirmatory phase show that the statements initially grouped under factor 1 were en-bloc under factor 2 and those under factor 2 were repositioned/reclassified en-bloc under factor 1 . The elements of factor 3 remained attached to the same factor. Slight changes in loadings are noted. Interestingly, 
the correlations between the factors (.61 to .74) are less than .85 indicating no significant conflict in discriminant validity (Sun, 2005) while $73.68 \%$ of the loadings of the different statements under the different factors are e" at .70 suggesting a good degree of convergent validity.

\section{Table 3}

Loading of Statements by Factor and Quality of Representation in the QuasiConfirmatory Factor Analysis

\begin{tabular}{|c|c|c|c|}
\hline & Items retained & Loadings & Communities \\
\hline \multirow[t]{7}{*}{$\begin{array}{c}\text { Factor } \\
1\end{array}$} & $\begin{array}{l}\text { E. } 24 \text { Gather information to identify students' strengths and } \\
\text { challenges. }\end{array}$ & .66 & .61 \\
\hline & $\begin{array}{l}\text { E. } 25 \text { Adapt my interventions according to the information } \\
\text { collected beforehand in order to promote learning progression. }\end{array}$ & .66 & .70 \\
\hline & $\begin{array}{l}\text { E. } 26 \text { Establish a balance sheet of the students' achievements } \\
\text { in order to assess their degree of acquisition of competencies. }\end{array}$ & .76 & .63 \\
\hline & E.27 Building tools to assess competency acquisition. & .69 & .59 \\
\hline & $\begin{array}{l}\text { E. } 28 \text { Communicate clearly and explicitly to students their } \\
\text { results from the evaluation process. }\end{array}$ & .85 & .66 \\
\hline & $\begin{array}{l}\text { E. } 29 \text { Communicating to different stakeholders (colleagues, } \\
\text { parents) the student's results of the evaluation process. }\end{array}$ & .88 & .64 \\
\hline & $\begin{array}{l}\text { E. } 30 \text { Collaborate with the school team in determining the } \\
\text { desired pace and stages of the pupils' learning progression. }\end{array}$ & .71 & .49 \\
\hline \multirow[t]{6}{*}{$\begin{array}{l}\text { Factor } \\
\quad 2\end{array}$} & $\begin{array}{l}\text { E.5 Anticipate obstacles and difficulties that students may } \\
\text { encounter in a teaching-learning situation. }\end{array}$ & .72 & .51 \\
\hline & $\begin{array}{l}\text { E. } 6 \text { Provide learning situations that allow for the integration } \\
\text { of the competencies covered by the training program. }\end{array}$ & .64 & .50 \\
\hline & $\begin{array}{l}\text { E. } 7 \text { Create conditions for students to engage in teaching- } \\
\text { learning situations taking into account their characteristics. }\end{array}$ & .79 & .57 \\
\hline & $\begin{array}{l}\text { E. } 8 \text { Guide students through appropriate interventions in the } \\
\text { completion of learning tasks. }\end{array}$ & .68 & .59 \\
\hline & $\begin{array}{l}\text { E. } 13 \text { Clearly present the activity (instructions, rules, criteria, } \\
\text { etc.). }\end{array}$ & .73 & .58 \\
\hline & E.14 Use adequate demonstration. & .77 & .53 \\
\hline \multirow[t]{6}{*}{$\begin{array}{c}\text { Factor } \\
3\end{array}$} & $\begin{array}{l}\text { E.31 Establish rules and routines for effective classroom } \\
\text { activities. }\end{array}$ & .70 & .64 \\
\hline & $\begin{array}{l}\text { E. } 32 \text { Communicate my expectations about appropriate } \\
\text { behaviour to students. }\end{array}$ & .73 & .66 \\
\hline & $\begin{array}{l}\text { E. } 33 \text { Involve students in establishing the rules of the class- } \\
\text { room. }\end{array}$ & .76 & .49 \\
\hline & $\begin{array}{l}\text { E. } 34 \text { Adopt strategies to prevent the occurrence of disruptive } \\
\text { behaviour. }\end{array}$ & .87 & .69 \\
\hline & E.35 Intervene effectively when disruptive behaviour occurs. & .79 & .58 \\
\hline & E.36 Maintain a climate conducive to learning. & .77 & .64 \\
\hline
\end{tabular}

Quasi-confirmatory analysis was used to calculate four recommended indices of fit when verifying the construct validity of an instrument (Sun, 2005) (Table 4). According to Sun (2005), the selection of more than one index is good practice, since each one 
assesses the goodness of fit differently and is based on different assumptions. He adds (p. 242): "moreover, fit indices vary in their appropriateness for specific circumstances in which goodness of fit is assessed. Therefore, different fit indices may be suitable for different purposes and circumstances, and the choice of fit indices may sometimes affect the interpretation of results".

\section{Table 4}

Summary of the Results of the Quasi-Confirmatory Factor Solution

\begin{tabular}{cccc}
\hline \multirow{2}{*}{ Items analysed } & \multicolumn{3}{c}{ Results } \\
\cline { 2 - 4 } & Obtained & Reference values \\
\hline RMSR & .04 & $<$ & .08 (Browne and Cudeck, 1993) \\
CFI & .99 & $>$ & .96 (Schmitt, 2011) \\
RMSEA & .05 & $<$ & .06 (Schmitt, 2011) \\
NNFI & .99 & $>$ & .95 (Cangur and Ercan, 2015) \\
\hline
\end{tabular}

Two of the selected indices, the root mean square error of approximation (RMSEA) and the comparative fit index (CFI) are based on an estimate of the difference between the reproduced and the unknown population covariance matrix. The RMSEA is absolute because it relates only to the hypothetical model, while the CFI is relative because it is compared to a basic model with parameters set at 0 (Sun, 2005). The other two, the non-normed fit index (NNFI) and the root mean square of residuals (RMSR) are indices based on the observed difference between the reproduced and sample covariance matrices. The first is said to be absolute while the other is qualified as relative. Schmitt (2011) points out, however, that these indices are only guides and should not be interpreted as golden rules for ensuring the quality of the factor solutions found.

\section{Discussion}

The research outlined in this article was aimed at developing a tool to study the perceptions of Quebec student teachers about their PSE in relation to professional competencies related to the act of teaching during a long practicum. The article describes the steps taken to develop, validate and verify the psychometric qualities of this tool. The tool was developed based on the four professional competencies related to the act of teaching (Competencies 3, 4, 5 and 6) identified in the Quebec referential of professional competencies (Government of Quebec, 2001) and based on the recommendations of Bandura $(2012 ; 2006)$ in his guide to the construction of a measurement scale for PSE.

It should be noted that 36 statements that relate to the act of teaching in the context of physical education instruction were first developed in consideration of Bandura's $(2012$; 2006) recommendations regarding the writing of statements and the development of the ordinal scale. An initial version of the questionnaire was tested with a small group of fourth-year teacher candidates from a pre-service PHE teacher education program for readability, length, and organization.

An initial wave of exploratory factor analyses led to a significant reduction $(47.22 \%)$ in the initial number of statements or items. This exploratory phase was necessary. Indeed, although the work of Desbiens, Alem and Oddson (2015) on the use of the teaching referential of competencies to assess the level of competency of graduating 
trainees showed that it was possible to reduce the number of factors condensing all of the competency components to four, we were working in the absence of a strong theory supporting the definition and grouping of each competency and the components of the referential. The version composed of 19 statements was deemed satisfactory because of the proportion of variance explained $(>66.0 \%)$, the value of the communities $(>.40)$ and the value of the loadings (.64 to .89) and, above all, because of the appropriateness of the ranking of the statements compared to what the study by Desbiens et al. (2015) and the referential, as drafted by the Quebec Ministry of Education (2001), allowed us to anticipate. With the exception of the statements associated with competencies 3 and 4, which have been merged into Factor 1 (Planning and Piloting), the other two factors include statements associated with competencies 5 (Evaluation) and 6 (Classroom management), respectively. The partial merging of the planning competency with the piloting competency could be explained by the complementary nature of the competencies in the referential (Government of Quebec, 2001). Indeed, some competencies would benefit from being intertwined with others since they are experienced and deployed in the context of a specific situation or a family of real-life situations (Government of Quebec, 2001; Guillemette \& Gauthier, 2006; Tardif, 2017). According to Wanlin (2009), when planning, teachers' thoughts are mainly directed towards their need to continuously control the pace of teaching-learning situations so that the content to be taught is covered and the objectives set are achieved at the end of the course and at the end of the year. The idea of piloting refers to "a to-and-fro between the perceived results of the teaching process and the planning of subsequent processes" (Wanlin, 2009, p. 121). In this context, teachers are called upon to be flexible to continually adjust their teaching (piloting) and manage planning dilemmas.

A further step was taken by subjecting this version to quasi-confirmatory verification, i.e., statistical checks to control the goodness of fit to the data in the proposed model. This verification was conclusive because, as the results show, it did not lead to the withdrawal of new statements and did not change their classification; the four adjustment measures reported successfully meet the strict cut-off lines prescribed by the scientific literature; and, finally, because the results obtained for discriminant and convergent validity are satisfactory. Clearly, the findings at this stage do not discredit the model we have identified. However, further research with another larger sample from the same population is, however, required in order to confront the results obtained and truly compare on a fully confirmatory basis competing hypotheses with the model presented here.

Although the psychometric qualities obtained are satisfactory, it seems important to mention some of the limitations of this study. First, it is important to draw attention to the size of the sample used. Although the factor solution in our questionnaire is fairly robust, it seems reasonable to us to validate the results obtained with a larger sample. Next, it is important to mention that the validation of our questionnaire was carried out among graduating trainees in PHE in Quebec. Thus, before using this questionnaire with trainees from different training programs and with distinct characteristics, a new empirical validation is required.

Until now, education researchers in the province of Quebec did not have an instrument measuring the PSE of physical and health education student trainees that took into account the referential of teaching competencies and whose psychometric qualities were presented in a clear and transparent manner. This study, which is still preliminary, 
given the original contextualized (in PHE programs in Quebec) and validated questionnaire, could help empirically measure the perception of self-efficacy among some Quebec student teachers related to the act of teaching. More specifically, this measurement scale allows us to study the perceptions of Quebec student teachers regarding their PSE in relation to each of the components related to the four professional competencies (C34-5 and 6) of the act of teaching. In addition to the fact that this scale provides trainees with an opportunity to become aware of their ability to carry out each of the actions related to these four competencies, it also allows them to identify the actions for which their PSE needs to be strengthened. As such, as a team, the cooperating teacher and trainee could use the perceptions from this scale as a starting point to identify concerns that may be negatively correlated with the effectiveness variables (Boz \& Boz, 2010).

Indeed, future teachers with fewer concerns tend to have a higher sense of selfefficacy compared to those who express more concern. The latter should be given the opportunity to discuss their concerns with their practicum teachers (Chance, 2000), and to reflect together on how to address these concerns. In this context, cooperating teachers use verbal persuasion to advise, support, encourage, and provide ongoing encouragement and constructive feedback to help teacher candidates move beyond their concerns and thereby enhance their sense of self-efficacy (Amamou et al., 2018; Boz \& Boz, 2010). Cooperating teachers are also encouraged to pay particular attention to the actual enactive mastery offered to trainees (Amamou et al., 2018; Flynn \& Chow, 2018). Indeed, this source is considered the most influential in terms of information on their self-efficacy (Bandura, 2007). It would therefore be recommended that the cooperating teacher exposes the trainees to different adapted situations to provoke their learning; for example, trainees should be offered progressive challenges, at their own measure, rhythm and reach; be pushed to surpass themselves by being allowed to get out of their comfort zone and should be questioned about their effectiveness. This coaching strategy would have the advantage of ensuring their experience of success and leading them to reflect on their practices (Amamou et al., 2018; Dassa \& Nichols, 2019; Desbiens et al., 2019a).

\section{Conclusions}

Administering this scale at different points in the teacher education process could provide teacher candidates' supervisors with indicators of the teacher candidates' PSE level and concerns. These indicators would allow them to adapt their coaching practices to the needs of their trainees to better support them in developing their perceptions related to their teaching competencies.

In terms of perspectives, future studies - including ours - that will adopt this robust measurement scale, could contribute to a better understanding of how trainees perceive their PSE and how it evolves over the course of the training program. These future studies will also contribute to the emergence of avenues for reflection and action for the implementation of effective systems adapted to initial teacher training in order to avoid under- or over-estimation of PSE by trainees (Dassa \& Nichols, 2019).

In terms of potential benefits, supporting the PSE of future teachers, by adapting support measures to their needs, will not only lead them to become more involved in their training process, which will have a potential effect on their learning and their development of professional teaching skills, but they will also tend, in the longer term, 
to be successful in their professional practice, to prove a satisfaction in their work and to adapt more adequately to professional challenges in the beginning of their career (Flynn \& Chow, 2018; Hattie, 2009).

The PSE could therefore become a booster (Bandura, 2007) for future teachers to better deal with the reality of the teaching profession and the classrooms in the school, knowing that $82 \%$ of new graduates indicate that they are insufficiently prepared for it at the conclusion of their initial training (Karsenti et al., 2015). In this regard, the valorisation of teaching internships and the improvement of support for future teachers in order to better support their PSE (Amamou \& Desbiens, 2018; Karsenti et al., 2015; Karsenti, Collin, \& Dumouchel, 2013) seems to us one of the most promising solutions that would allow education systems to counter the professional dropout, or at least, to decrease the alarming rate of $25 \%$ to $30 \%$ after the first year of a career and which rises to $50 \%$ after the first five years (Létourneau, 2014).

\section{References}

Amamou, S., Ben Alaya, I., Desbiens, J. F., et al., Vandercleyen, F. (2018). Analyse critique des démarches de vérification des qualités psychométriques des échelles de mesure du sentiment d'efficacité personnelle [Critical analysis of approaches to verifying the psychometric qualities of self-efficacy measurement scales]. $5^{\text {th }}$ International Colloquium on Education, Quebec City, Canada, May 3 and 4.

Amamou, S., Desbiens, J. F., \& Vandercleyen, F. (2018). L'essentiel rôle du sentiment d'efficacité personnelle pour les stagiaires: La cible à privilégier lors de la formation initiale des enseignants. [The essential role of self-efficacy for the trainees: The target to be favored during initial teacher training]. Education Canada, 58(3), 38-39.

Amamou, S., Desbiens, J. F., Spallanzani, C., \& Vandercleyen, F. (2017). Évolution du sentiment d'efficacité personnelle à gérer la classe de stagiaires en formation à l'enseignement en éducation physique et à la santé [Change in sense of self-efficacy in managing the health and physical education teacher education trainee classroom]. PHEnex Journal, 9(1), 1-18.

Baglin, J. (2014). Improving your exploratory factor analysis for ordinal data: A demonstration using FACTOR. Practical Assessment, Research \& Evaluation, 19(5), 1-15.

Bandura, A. (1977). Self-efficacy: Toward a unifying theory of behavioral change. Psychological Review, 84(2), 191-215.

Bandura, A. (1986). The explanatory and predictive scope of self-efficacy theory. Journal of Clinical and Social Psychology, 4, 359-373.

Bandura, A. (1997). Self-efficacy: The exercise of control. New York, NY: Freeman.

Bandura, A. (2006). Guide for constructing self-efficacy scales. In F. Pajares \& T. Urban (Eds.), Self-efficacy beliefs of adolescents (pp. 307-337). Greenwich, CT: Information Age.

Beavers, A. S., Lounsbury, J. W., Richards, J. K., Huck, S. W., Skolits, G. J., \& Esquivel, S. L. (2013). Practical considerations for using exploratory factor analysis in educational research. Practical Assessment, Research \& Evaluation, 18(6), $1-13$.

Beckers, J. (2007). Compétences et identités professionnelles: l'enseignement et autres métiers de l'interaction humaine [Professional skills and identities: Teaching and other human interaction professions]. Bruxelles: De Boeck. 
Beckers, J., Andrianne, S., Bourguignon, L., Jardon, D., Jaspar, S., \& Mathieu, C. (2002). Pour un dispositif favorisant une insertion réussie dans la vie professionnelle [For a system that promotes successful integration into working life]. University of Liege: Service of general didactics.

Behets, D., \& Vergauwen, L. (2006). Learning to teach in the field. In D. Kirk, D. Macdonald, \& M. O'Sullivan (Eds.), The handbook of physical education (pp. 408421). Thousand Oaks, CA: Sage Publications.

Bourque, J., Doucet, D., LeBlanc, J., Dupuis, J., \& Nadeau, J. (2019). L’alpha de Cronbach est l'un des pires estimateurs de la consistance interne: une étude de simulation [Cronbach's alpha is one of the worst estimators of internal consistency: A simulation study]. Journal of Educational Sciences, 45(2), 78-99.

Bourque, J., Poulin, N., \& Cleaver, A. F. (2006). Évaluation de l'utilisation et de la présentation des résultats d'analyses factorielles et d'analyses en composantes principales en éducation [Evaluation of the use and presentation of the results of factor analysis and principal component analysis in education]. Journal of Educational Sciences, 32(2), 325-344.

Boz, Y., \& Boz, N. (2010). The nature of the relationship between teaching concerns and sense of efficacy. European Journal of Teacher Education, 33(3), 279-291.

Capel, S., \& Breckon, P. (2014). A practical guide to teaching physical education in the secondary school (2 ${ }^{\text {nd }}$ Eds.). New York: Routledge.

Caprara, G. V., Barbaranelli, C., Steca, P., \& Malone, P. S. (2006). Teachers' selfefficacy beliefs as determinants of job satisfaction and students' academic achievement: A study at the school level. Journal of School Psychology, 44(6), 473-490.

Clark, S. K., Byrnes, D., \& Sudweeks, R. R. (2015). A comparative examination of student teacher and intern perceptions of teaching ability at the pre-service and inservice stages. Journal of Teacher Education, 66(2), 170-183.

Costello, A. B., \& Osborne, J. (2005). Best practices in exploratory factor analysis: four recommendations for getting the most from your analysis. Practical Assessment Research \& Evaluation, 10(7), 1-9.

Dassa, L., \& Nichols, B. (2019). Self-efficacy or overconfidence? Comparing preservice teacher self-perceptions of their content knowledge and teaching abilities to the perceptions of their supervisors. New Educator, 15(2), 156-174.

Dejean, K. (2010). Les transactions de reconnaissance dans le parcours d'insertion professionnelle des enseignants débutants. Développement identitaire et dimensions émotionnelles. Communication à l'occasion de la journée d'étude "Piloter - Mobiliser - Accompagner", Le rôle du chef d'établissement, organisée par l'Institut d'administration scolaire (INAS) [Recognition transactions in the professional integration path of beginning teachers. Identity development and emotional dimensions. Communication on the occasion of the study day "Piloting - Mobilizing Accompanying", The role of the headteacher, organized by the Institute of School Administration (INAS)], Université of Mons.

Desbiens, J. F., Habak, A., \& Martineau, S. (2019a). Analyser l'expérience du stage en enseignement au travers du prisme des difficultés et des échecs de stagiaires québécois: réflexion basée sur les écrits spécialisés [Analyzing the experience of the teaching internship through the prism of the difficulties and failures of Quebec interns: Reflection based on specialized writings], Éducation and socialisation, 54. 
Desbiens, J. F., Correa-Molina, E., et al., Habak, A. (2019b). Alternance, discontinuités et difficultés rencontrées en formation initiale des enseignants [Alternation, discontinuities and difficulties in initial teacher training]. Education \& Formation, e-314, November, 69-84.

Desbiens, J. F., Bali, N., Spallanzani, C., Vandercleyen, F., \& Beaudoin, S. (2018). Validation d'un instrument pour mesurer les préoccupations d'enseignants stagiaires en ÉPS tunisiens [Validation of an instrument to measure the concerns of Tunisian PSE trainee teachers]. Anadolu University Journal of Education Faculty (AUJEF), 2(2), 158-177.

Desbiens, J. F., Borges, C., \& Spallanzani, C. (2012). J'ai mal à mon stage: problèmes et enjeux de la formation pratique en enseignement [My practicum hurts: Problems and issues in practical teacher education]. Sainte-Foy: Presses de l'Université du Québec.

Field, A. (2013). Discovering statistics using IBM SPSS statistics (4 ${ }^{\text {th }}$ Eds.). Los Angeles, Sage.

Flora, D. B., \& Curran, P. J. (2004). An empirical evaluation of alternative methods of estimation for confirmatory factor analysis with ordinal data. Psychological Methods, 9(4), 466-491.

Flores, I. M. (2015). Developing preservice teachers' self-efficacy through field-based science teaching practice with elementary students. Research in Higher Education Journal, 27, 1-19.

Flynn, D., \& Chow, P. (2018). Self-efficacy, self-worth and stress. Education, 138(1), 3-8.

Fortin, M. F., \& Gagnon, J. (2016). Fondements et étapes du processus de recherche: Méthodes quantitatives et qualitatives (3ed. Ed.) [Foundations and steps in the research process: Quantitative and qualitative methods (3 ${ }^{\text {rd }}$ edition)]. Montréal, Québec: Chenelière éducation.

Gardner, D. G., \& Pierce, J.L. (1998). Self-esteem and self-efficacy within organizational context. Group and Organisation Management, 23(1), 48-70.

Garrahy, D., Cothran, D., \& Kulinna, P. H. (2002, April). Teachers' perspectives on classroom management in elementary physical education. Annual meeting of the American Education al Research Association. LA: New Orleans.

Gaudreau, N. (2011). La gestion des problèmes de comportement en classe inclusive: pratiques efficaces [Managing nehavioural problems in the inclusive classroom: Effective practices]. Education \& Francophonie, 39(2), 122-144.

Gaudreau, N., Royer, É., Beaumont, C., \& Frenette, É. (2012). Gestion positive des situations de classe: un modèle de formation en cours d'emploi pour aider les enseignants du primaire à prévenir les comportements difficiles des élèves [Positive management of classroom situations: An in-service training model to help elementary school teachers prevent difficult student behaviour]. Enfance en difficulté, 1, 85-115.

Gibson, S., \& Dembo, M.-H. (1984). Teacher efficacy: A construct validation. Journal of Educational Psychology, 76(4), 569-582.

Guillemette, F., \& Gauthier, C. (2006). L'approche par compétences (APC) en formation des maitres: analyse documentaire et critique [The competency-based approach (CBA) to teacher education: Literature review and critical analysis]. Éduquer (Cahiers Binet-Simon), 11, 137-179. 
Gouvernement of Québec. (2001). La formation à l'enseignement. Les orientations. Les compétences professionnelles [Teacher training. Orientations. Professional skills]. Quebec: Quebec Ministry of Education. http://www.education.gouv.qc.ca/ fileadmin/site_web/documents/reseau/formation_titularisation/formation_ enseignement_orientations_EN.pdf

Gurl, T. J. (2019). Classroom practices of cooperating teachers and their relationship to collaboration quality and time: perceptions of student teachers. Teaching Education, 30(2), 177-199. doi: 10.1080/10476210.2018.1457635

Hair, J. F., Black, W. C., Babin, B. J., Anderson, R. E., \& Tatham, R. L. (2006). Multivariate data analysis ( $6^{\text {th }}$ Eds.). Upper Saddle River NJ: Pearson-Prentice Hall.

Hattie, J. A. C. (2009). Visible learning: A synthesis of over 800 meta-analyses relating to achievement. London, UK: Routledge.

Heasly, B., Lindner, J., Iliško, D., \& Salite, I. (2020). From initiatives, to insights, to implementation of the sustainability and securitability agenda for 2030. Discourse and Communication for Sustainable Education, 11(1), 1-4.

Horn, J. L. (1965). A rationale and test for the number of factors in factor analysis. Psychometrika, 30, 179-185.

Hoy, A. W., \& Spero, R. B. (2005). Changes in teacher efficacy during the early years of teaching: A comparison of four measures. Teaching and Teacher Education, 21(4), 343-356.

Ingersoll, R. M. (2001). Teacher turnover and teacher shortages: An organizational analysis. American Educational Research Journal, 38(3), 499-534.

Ingersoll, R., Merrill, L., \& Stuckey, D. (2014). Consortium for policy research in education. Seven Trends: The transformation of the teaching force. Updated April 2014. CPRE Report. pass: [\#] RR-80. Consortium for Policy Research in Education.

Jobin, V., \& Gauthier, C. (2009, January). Le référentiel de compétences professionnelles en formation à l'enseignement au Québec et sa transposition dans les pratiques des formateurs de maitres [The professional competency framework for teacher education in Quebec and its transposition into the practices of teacher educators]. Paper presented at the $21^{\text {st }}$ Colloquium of ADMEE-Europe, Louvain-La-Neuve, Belgium.

Jones, E., \& Nimmo, J. (1999). Collaboration, conflict, and change: Thoughts on education as provocation. Young Children, 54(1), 5-10.

Karsenti, T., Correa Molina, E. A., Desbiens, J. F., Gauthier, C., Gervais, C., Lepage, M., Lessard, C., Martineau, S., Mukamurera, J., Raby, C., Tardif, M., \& Collin, S. (2015). Analyse des facteurs explicatifs et des pistes de solution au phénomène du décrochage chez les nouveaux enseignants, et de son impact sur la réussite scolaire des élèves [Analysis of the explanatory factors and possible solutions to the dropout phenomenon among new teachers and its impact on students' academic success]. (Rapport Nr. 2012-RP-147333). Montréal, Québec: University of Montréal.

Karsenti, T., Collin, S., \& Dumouchel, G. (2013). Le décrochage enseignant: état des connaissances [Teacher dropout: State of knowledge]. International Review of Education, 59(5), 549-568.

Klassen, R. M., Tze, V. M. C., Betts, S. M., \& Gordon, K. A. (2011). Teacher efficacy research 1998-2009: Signs of progress or unfulfilled promise? Educational Psychology Review, 23(1), 21-43.

Koskela, R., \& Ganser, T. (1998). The cooperating teacher role and career development. Education, 119, 106-125. 
Kosnik, C. (2009). It is not Just Practice: Conflicting goals, unclear expectations. In F. J. Benson \& C. Riches (Eds.), Engaging in conversations about ideas in teacher education (pp. 65-71). New York: Falmer Press.

Lévy-Leboyer, C. (2009). La gestion des compétences (2 ${ }^{\text {nd }}$ Eds.) [The management of competencies ( $2^{\text {nd }}$ Ed.) ]. Paris, France: Organisation Edition.

Ma, K., \& Cavanagh, M. S. (2018). Classroom Ready? Pre-service teachers' self-efficacy for their first professional experience placement. Australian Journal of Teacher Education, 43(3), 134-151.

Mardia, K. V. (1970). Measures of multivariate skewness and kurtosis with applications. Biometrika, 57, 519-530.

Matanin, M., \& Collier, C. (2003). Longitudinal analysis of preservice teachers' beliefs about teaching physical education. Journal of Teaching in Physical Education, 22(2), 153-168.

Mukamurera, J., \& Gingras, C. (2005). La formation initiale vue par des enseignants du secondaire issus des programmes de formation en cours au Québec depuis 1970 [Pre-service training as seen by secondary school teachers from the training programs in place in Quebec since 1970]. In C. Gervais \& L. Portelance (Eds.), Des savoirs au cour de la profession enseignante. Contextes de construction et modalités de partage [Knowledge at the heart of the teaching profession. Contexts of construction and modalities of sharing] (pp. 45-63). Sherbrooke, QC: Editions du CRP.

O'Connor, B. P. (2000). SPSS and SAS programs for determining the number of components using parallel analysis and Velicer's MAP test. Behavior Research Methods, Instruments \& Computers, 32(3), 396-402.

OECD (2014). TALIS 2013 Results. OECD Publishing. http://www.oecd-ilibrary.org/ education/talis-2013-results_9789264196261-en

Razali, N. M., \& Wah, Y. B. (2011). Power comparisons of Shapiro-Wilk, KolmogorozSmirnov, Lilliefors and Anderson-Darling tests. Journal of Statistical Modeling and Analytics, 2(1), 21-33.

Salite, I. (2016). Searching for sustainability in teacher education and educational research: Experiences from the Baltic and Black Sea Circle Consortium for educational research. Discourse and Communication for Sustainable Education, 6(1), 21-29.

Schmitt, T. A. (2011). Current methodological considerations in exploratory and confirmatory factor analysis. Journal of Psychoeducational Assessment, 29(4), 304321.

Schwarzer, R., Schmitz, G. S., \& Daytner, G.-T. (1999). The teacher self-efficacy scale [On-line publication]. http://www.fu-berlin.de/gesund/skalen/t_se.htm

Sharma, U., Loreman, T., \& Forlin, C. (2012). Measuring teacher efficacy to implement inclusive practices. Journal of Research in Special Educational Needs, 12(1), 12-21.

Skaalvik, E. M., \& Skaalvik, S. (2007). Dimensions of teacher self-efficacy and relations with strain factors, perceived collective teacher efficacy, and teacher burnout. Journal of Educational Psychology, 99, 611-625.

Stafford, J., \& Bodson, P. (2006). L'analyse multivariée avec SPSS [Multivariate analysis with SPSS]. Quebec: Presse of Quebec University.

Sun, J. (2005). Assessing goodness of fit in confirmatory factor analysis. Measurement \& Evaluation in Counseling \& Development, 37(4), 240-256. 
Tardif, J. (2017). Des repères conceptuels à propos de la notion de compétence, de son développement et de son évaluation [Conceptual benchmarks about the notion of competency, its development and assessment]. In M. Poumay, J. Tardif, \& F. Georges (Eds.), Organiser la formation à partir des compétences [Organize training based on skills] (pp. 15-37). Bruxelles: De Boeck.

Tschannen-Moran, M., \& Woolfolk-Hoy, A. (2001). Teacher efficacy: Capturing an elusive construct. Teaching and Teacher Education, 17, 783-805.

Veenman, S. (1984). Perceived problems of beginning teachers. Review of Educational Research, 54(2), 143-178.

Wanlin, P. (2009). La pensée des enseignants lors de la planification de leur enseignement [Teachers' thinking when planning their teaching]. Revue française de pédagogie, 166, 89-128.

Weinstein, C. S. (1989). Teacher education students' preconceptions of teaching. Journal of Teacher Education, 40(2), 53-60.

Wheatley, K. F. (2002). The potential benefits of teacher efficacy doubts for educational reform. Teaching and Teacher Education, 18(1), 5-22.

Yilmaz, C. (2011). Teachers' perceptions of self-efficacy, English proficiency, and instructional strategies. Social Behavior and Personality: An International Journal, 39(1), 91-100.

Correspondence concerning this paper should be addressed to Salem Amamou, University of Quebec in Abitibi-Temiscamingue, Quebec, Canada. Email: Salem.Amamou@uqat.ca 